\title{
30. AGE AND CHEMISTRY OF VOLCANIC ROCKS DREDGED FROM JINGŪ SEAMOUNT, EMPEROR SEAMOUNT CHAIN ${ }^{1}$
}

\author{
G. Brent Dalrymple, U.S. Geological Survey, Menlo Park, California
}

and

Michael O. Garcia, Hawaii Institute of Geophysics, University of Hawaii at Manoa, Honolulu, Hawaii

\begin{abstract}
${ }^{40} \mathrm{Ar} /{ }^{39} \mathrm{Ar}$ incremental heating experiments on three samples dredged from Jingū Seamount indicate that Jingū is $55.4 \pm 0.9$ m.y. old - older than the Hawaiian-Emperor bend and younger than the two dated Emperor Seamounts to the north. Major-oxide chemistry and petrography show that the samples are similar to hawaiites and mugearites from the Hawaiian Islands. By analogy with Hawaiian alkalic volcanic rocks, groundmass plagioclase compositions $\left(\mathrm{An}_{40-47}\right)$ indicate that the three Jingū samples are probably mugearites. These results suggest that Jingu is a Hawaiian-type volcano and that the Emperor volcanoes become progressively older from south to north, as predicted by the hot-spot hypothesis.
\end{abstract}

\section{INTRODUCTION}

Jingū Seamount, one of the major volcanic structures in the Emperor Seamount chain, is located about 675 $\mathrm{km}$ north of the Hawaiian-Emperor bend (Figure 1). This guyot is elongated in a north-south direction, and abuts Ojin Seamount to the south. Jingū probably consists of a single volcanic edifice (shield number 83 of Bargar and Jackson, 1974). From seismic evidence, Greene et al. (1978) have shown that Jingū, like most of the seamounts in the central and southern Emperor chain, is capped by reef deposits and was probably once a volcanic island.

The hot-spot hypothesis was first proposed by Wilson (1963) to explain the origin of the Hawaiian Islands, and later was extended by Christofferson (1968) and Morgan (1972) to include the Emperor Seamounts. According to this hypothesis, the volcanoes of the Hawaiian-Emperor chain formed as the Pacific lithospheric plate moved, first northward, then westward, over a fixed melting anomaly in the asthenosphere. Two important corollaries of the hot-spot hypothesis predict that for the Hawaiian-Emperor chain (1) the inception of volcanism for eruptive centers should increase with distance from the active volcanoes of Kilauea and Mauna Loa on the island of Hawaii, and (2) the volcanoes along the length of the chain are chemically and structurally similar, or at least have evolved in a systematic way. These predictions are supported by $\mathrm{K}-\mathrm{Ar}$ dating and chemical studies for the Hawaiian chain, the Hawaiian-Emperor bend, and the southernmost Emperor Seamounts (see recent summaries in Jackson, 1976; Dalrymple and Clague, 1976; Jarrard and Clague, 1977), but until recently (this volume) there have been no data for the volcanoes north of Kōkō Sea-

${ }^{1}$ Hawaii Institute of Geophysics Contribution No. 1045. mount, one of the southernmost Emperor volcanoes (Figure 1)

We have studied three volcanic rocks dredged from Jingū Seamount in July of 1977 by the Hawaiian Institute of Geophysics R/V Kana Keoki. The purpose of the studies was to obtain age and chemistry data that would contribute to the test of the hot-spot hypotheses for the Emperor Seamount chain. The samples from Jingū are important to the hot-spot experiment because Jingū is one of only four seamounts north of Kōkō from which suitable samples have been recovered; the others are Ōjin (DSDP Site 430), Nintoku (Site 432), and Suiko (Site 433).

The Jingu samples were recovered from a depth of 1104 meters at $38^{\circ} 37.3^{\prime} \mathrm{N}, 171^{\circ} 02.4^{\prime} \mathrm{E}$, on the southwestern part of the seamount (Figure 1). The dredge haul contained about $124 \mathrm{~kg}$ of volcanic rocks, most moderately altered, with manganese crusts 1 to $20 \mathrm{~mm}$ thick. Three of the freshest samples were selected for $\mathrm{K}-\mathrm{Ar}$ dating and chemical analysis.

Whole-rock major-element analyses were determined by X-ray fluorescence for $\mathrm{Si}, \mathrm{Al}, \mathrm{Fe}$ (total), $\mathrm{Mg}$ (for high amounts), $\mathrm{Ca}, \mathrm{K}, \mathrm{Ti}$, and $\mathrm{Mn}$. Na and $\mathrm{Mg}$ (for small amounts) were analyzed by atomic absorption methods. P contents were determined by colorimetry. Ferrous iron was determined by titration, with sodium diphenylamine sulfonate as an indicator. To determine $\mathrm{H}_{2} \mathrm{O}$ values, each sample was heated in a stream of dry oxygen in an induction furnace at $1100^{\circ} \mathrm{C}$, then $\mathrm{H}_{2} \mathrm{O}$ was collected on anhydrone and weighed. For $\mathrm{CO}_{2}$ analyses, each sample was decomposed in warm $\mathrm{HCl}^{2}$. The evolved $\mathrm{CO}_{2}$ was passed through a drying train, collected on ascarite, and weighed. Chemical compositions of the Jingu samples are shown in Table 1.

Mineral analyses were made with an ARL-EMX electron microprobe. Instrument operating conditions were $15 \mathrm{kV}$ and $20 \mathrm{nA}$ sample current. Each analysis is an 

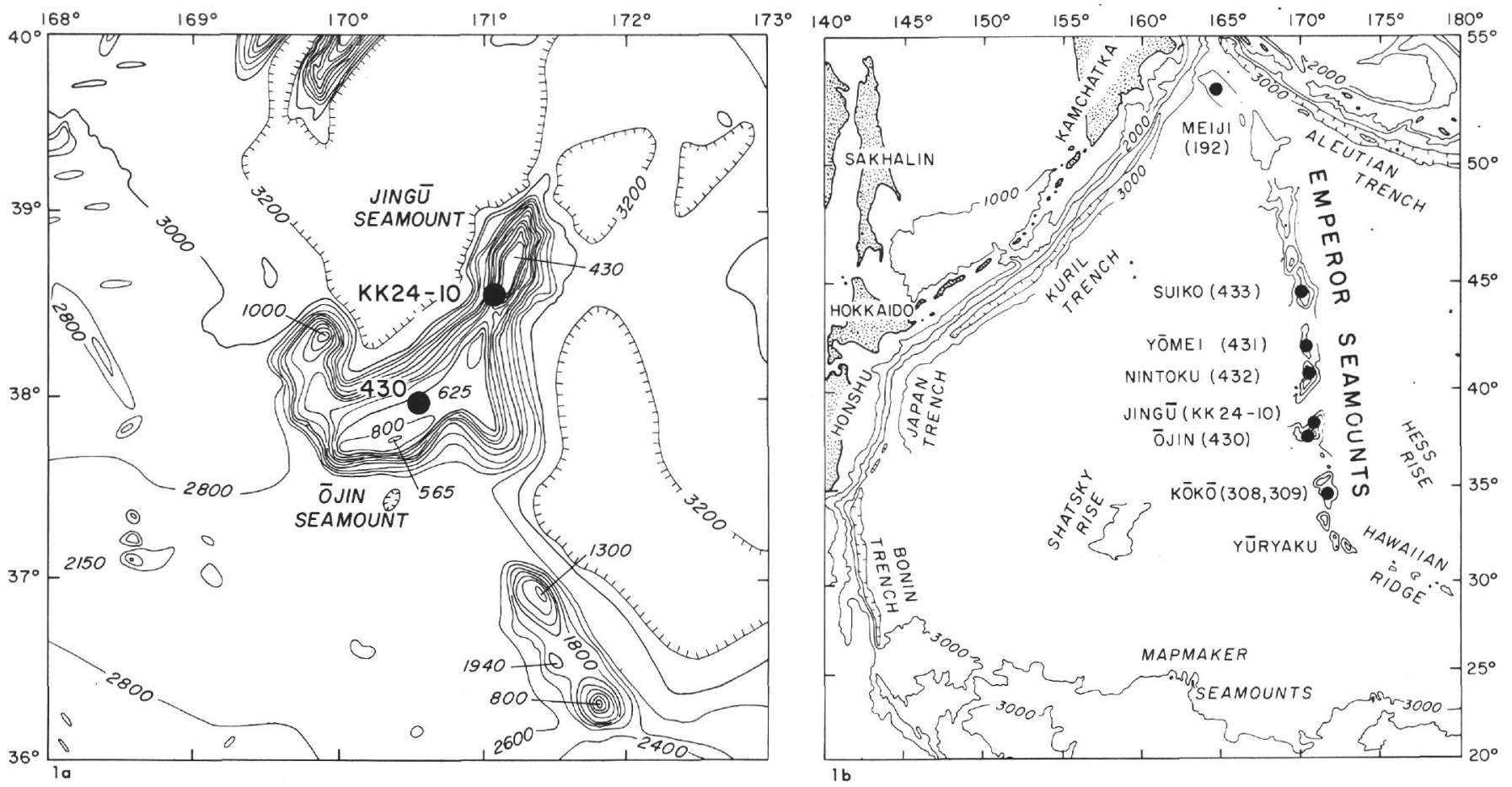

Figure 1. (a) Bathymetry of Jing $\bar{u}$ and $\bar{O} j$ jin Seamounts, showing locations of $R / V$ Kana Keoki station 24, dredge 10 (KK24-10), and DSDP Site 430. (b) Locations of R/V Kana Keoki station 24, dredge 10 (KK24-10), and of DSDP sites in the Emperor Seamount chain. Bathymetry in fathoms after Chase et al. (1970).

TABLE 1

Chemical Composition of Dredged Volcanic Rocks from Jingū Seamount, Emperor Volcanic Chain (wt. \%)

\begin{tabular}{lrrrrr}
\hline & KK24-10A & KK24-10B & KK24-10C & BCR-1 & BCR-1* \\
\hline $\mathrm{SiO}_{2}$ & 46.40 & 48.95 & 49.55 & 54.40 & 54.40 \\
$\mathrm{TiO}_{2}$ & 2.79 & 2.76 & 2.88 & 2.26 & 2.20 \\
$\mathrm{Al}_{2} \mathrm{O}_{3}$ & 16.31 & 16.18 & 16.46 & 13.58 & 13.61 \\
$\mathrm{Fe}_{2} \mathrm{O}_{3}$ & 13.00 & 9.56 & 9.83 & 3.54 & 3.68 \\
$\mathrm{FeO}$ & 0.24 & 2.56 & 2.24 & 8.80 & 8.80 \\
$\mathrm{MnO}$ & 0.16 & 0.12 & 0.14 & 0.18 & 0.18 \\
$\mathrm{MgO}$ & 1.98 & 3.34 & 2.78 & 3.43 & 3.46 \\
$\mathrm{CaO}$ & 7.83 & 6.92 & 6.97 & 6.92 & 6.92 \\
$\mathrm{Na} 2 \mathrm{O}$ & 4.11 & 4.20 & 3.99 & 3.28 & 3.27 \\
$\mathrm{~K}_{2} \mathrm{O}$ & 2.76 & 1.64 & 1.61 & 1.68 & 1.70 \\
$\mathrm{P}_{2} \mathrm{O}_{5}$ & 2.20 & 0.88 & 0.82 & 0.37 & 0.36 \\
$\mathrm{H}_{2} \mathrm{O}$ & 1.82 & 2.59 & 2.39 & 1.61 & 1.57 \\
$\mathrm{CO}_{2}$ & 0.28 & 0.05 & $\underline{0.03}$ & 0.02 & 0.03 \\
TOTAL & 99.88 & 99.75 & 99.69 & 100.07 & 100.28 \\
\hline
\end{tabular}

Note: $B C R-1=$ U.S. Geological Survey rock standard; internal control. BCR-1* = Preferred values of Flanagan (1973). Analyses as received. Analyst: K. Ramial, University of Manitoba.

average of four to six points from a small portion of a single grain (four to six grains per sample). Cores and rims were analyzed to check for zoning and overall homogeneity. Both internal and external standards were used; they were natural minerals from the UCLA collection. The internal standard was a well-analyzed andesine. Raw data were corrected for dead time of detectors, instrument current drift, and spectrometer background. Mineral analyses were obtained using the correction methods of Bence and Albee (1968) and Albee and Ray (1970). Accuracy, based on replicate microprobe analysis compared with wet chemical analysis, is estimated to be 1 to 2 percent for major elements and 5 to 10 per cent for minor elements.

Potassium measurements for $\mathrm{K}-\mathrm{Ar}$ dating were performed on whole-rock powders by flame photometry, after dissolution by lithium metaborate fusion (Ingamells, 1970). Samples for Ar analyses were either small cut blocks (conventional measurements) or cores $\left({ }^{40} \mathrm{Ar} /{ }^{39} \mathrm{Ar}\right.$ analyses), and were not crushed. Argon for conventional $\mathrm{K}-\mathrm{Ar}$ dating was measured by isotope dilution mass spectrometry, using techniques and equipment described by Dalrymple and Lanphere (1969) and Stacey et al. (1978). The ${ }^{40} \mathrm{Ar} /{ }^{39} \mathrm{Ar}$ total fusion and incremental heating measurements were performed after the samples had been irradiated in the U.S. Geological Survey TRIGA reactor (GSTR) for from 25 to $30 \mathrm{Mwh}$, where they received a neutron dose of about 2.5 to $3 \times$ $10^{18} \mathrm{nvt}$. The techniques, corrections, and methods of data reduction are described by Dalrymple and Lanphere $(1971,1974)$, Lanphere and Dalrymple (1971), and Dalrymple et al. (this volume). Constants used for age calculations are those recently recommended by the IUGS Subcommission on Geochronology (Steiger and Jäger, 1977); ages referenced from older literature have been recalculated using these new constants. Isochrons were calculated using the York 2 fit with correlated errors (York, 1969).

\section{CHEMISTRY AND PETROGRAPHY}

Petrographically and chemically, the Jingū samples closely resemble lavas of the Hawaiian alkalic suite, which commonly form a thin veneer on the tholeiitic 
shields of the principal Hawaiian Islands (Macdonald and Katsura, 1964; Macdonald, 1968).

Sample $24-10 \mathrm{~A}$ is oxidized and aphyric, with a very thin ( $<1 \mathrm{~mm}$ thick) manganese coating. The outer portion of the sample is highly vesicular (30 to $40 \%$ ) and fragmental. The interior of the sample has a subtrachytic texture with 5 to 10 per cent irregular vesicles, 0.25 to $1.0 \mathrm{~mm}$ in diameter, and a groundmass consisting of 50 to 55 per cent fresh plagioclase laths, 0.05 to $0.1 \mathrm{~mm}$ long, with intergranular olivine (5 to $10 \%$ ) that is almost completely altered to iddingsite and to clay minerals, clinopyroxene ( 0 to $5 \%$ ), mostly altered to yellow clay minerals, equant $\mathrm{Fe}$ oxides ( 30 to $40 \%$ ), and apatite (1 to $2 \%$ ) (Plate 1). The vesicularity, extremely high $\mathrm{Fe}_{2} \mathrm{O}_{3} / \mathrm{FeO}$ ratio, and lack of well-defined quenched textures indicate that the sample is probably from a subaerially erupted lava flow.

Samples 24-10B and $24-10 \mathrm{C}$ are nearly identical. Both are massive, with manganese crusts $1 \mathrm{~mm}$ thick and oxidation rinds $1 \mathrm{~cm}$ thick. Each sample has a welldeveloped trachytic texture and rare $(<1 \%)$ microphenocrysts of olivine, up to $0.4 \mathrm{~mm}$ across, that have been completely replaced by green and yellowish brown clays. The rocks comprise 65 to 70 per cent fresh plagioclase laths $\left(\mathrm{An}_{40-47}\right) 0.05$ to $0.1 \mathrm{~mm}$ long, 10 to 15 per cent equant $\mathrm{Fe}$-Ti oxides, a few per cent olivine altered to iddingsite, minor apatite, and 10 to 15 percent interstitial yellowish brown clay that may be, in part, altered glass (Plate 2). Sample 24-10C also contains rare phenocrysts of plagioclase $\left(\mathrm{An}_{45-55}\right) 5 \mathrm{~mm}$ long that are fractured and strained and may be xenocrystic. The samples lack any petrographic features that might indicate they are from submarine lava flows. Instead, they resemble subaerial samples altered in seawater.

Alteration presents a problem in classification of these samples. Cann (1969) and Hart et al. (1974) have shown that $\mathrm{K}_{2} \mathrm{O}$ and $\mathrm{Na}_{2} \mathrm{O}$ contents are particularly susceptible to submarine alteration. All these samples are moderately altered, contain at least 10 to 15 per cent iddingsite and clay, more than $1.8 \mathrm{wt}$. per cent water, and have high to extreme $\mathrm{Fe}_{2} \mathrm{O}_{3} / \mathrm{FeO}$ ratios. Therefore, normative plagioclase compositions (Macdonald, 1960; Muir and Tilley, 1961), $\mathrm{K}_{2} \mathrm{O}: \mathrm{Na}_{2} \mathrm{O}$ ratios (Macdonald and Katsura, 1964) and normative Or ':Ab ':An ' ratios (Streckeisen, 1976) are not appropriate for classifying these samples.

Fresh plagioclase grains are abundant in the samples. Coombs and Wilkinson (1969) state that modal and normative plagioclase compositions can be utilized in the classification of differentiated alkalic rocks. Andesine is present in hawaiites and oligoclase in mugearites. Unfortunately, microprobe analyses of groundmass plagioclase from hawaiites and mugearites show consistently higher An contents than those given by whole-rock normative analyses. For instance, groundmass plagioclase compositions of Hawaiian hawaiites range from $\mathrm{An}_{57}$ to $\mathrm{An}_{64}$, and mugearites range from $\mathrm{An}_{39}$ to $\mathrm{An}_{50}$ (Figure 2; Keil et al., 1972). Mugearites from Dunedin Volcano in New Zealand have groundmass plagioclase compositions of $\mathrm{An}_{40-48}$ (Price and Chappell, 1975). Thus, groundmass plagioclase compositions for hawaiites and mugearites do define distinct fields (Figure 2). Groundmass plagioclase compositions may therefore be useful for classification of alkalic volcanic rocks, particularly where the samples are altered.

The three samples from Jingū Seamount contain abundant calcic andesine $\left(\mathrm{An}_{40-47}\right)$ in the groundmass (Table 2; Figure 2). If the plagioclase analyses of unaltered samples from Hawaii and New Zealand are representative of the plagioclase compositions in most non-nepheline-bearing hawaiites and mugearites, then the Jingu Seamount samples may be classified as mugearites.

Interstitial material of feldspar composition is present in all three samples. It is not always morphologically distinct, and in most cases grades into groundmass plagioclase laths. It is distinguished by high sodium and potassium contents (Table 3; Figure 2), and extends the compositional range of feldspar through the anorthoclase field into potassium-feldspar compositions. Similar analyses are reported for alkalic rocks from Hawaii (Keil et al., 1972).

\section{K-Ar AGES}

Alteration of the samples recovered from Jingū Seamount is sufficiently extensive that none of the samples were expected to give reliable, conventional $\mathrm{K}-\mathrm{Ar}$ ages, but the primary constituent (plagioclase) is unaltered and all three were judged potentially amenable to ${ }^{40} \mathrm{Ar} /{ }^{39} \mathrm{Ar}$ incremental heating techniques.

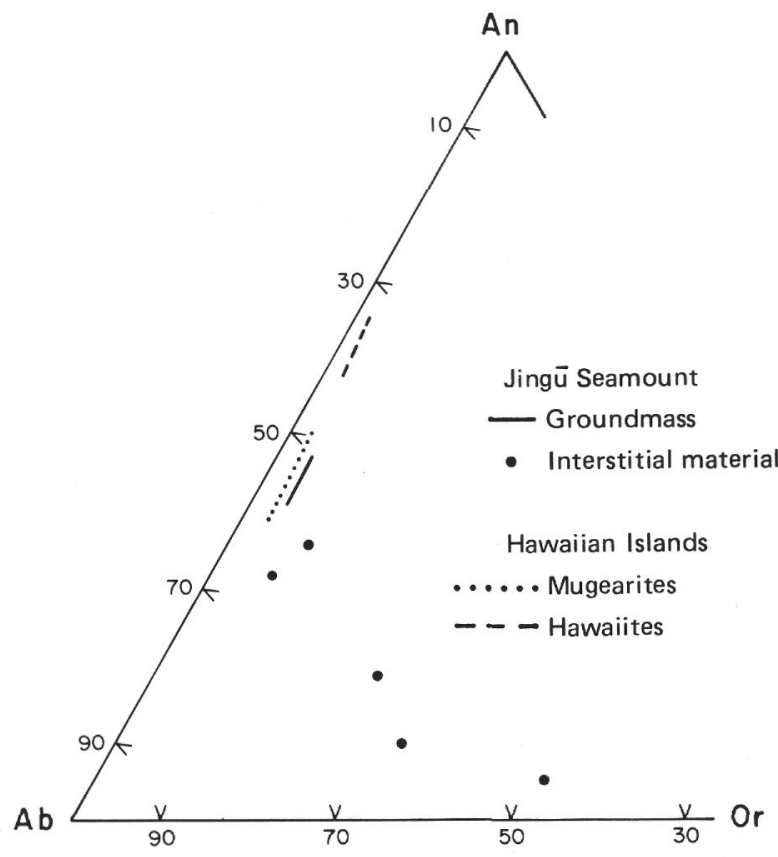

Figure 2. Compositions of groundmass feldspar from Jing $\bar{u}$ Seamount and Hawaiian mugearites and hawaiites (Keil et al., 1972) and interstitial material from Jing $\bar{u}$ Seamount, expressed in terms of mole \% anorthite (an), albite (ab), and orthoclase (or). 
TABLE 2

Plagioclase Compositions in Volcanic Rocks from Jingū Seamount, Emperor Seamount Chain (wt. \%)

\begin{tabular}{|c|c|c|c|c|c|}
\hline & $\begin{array}{c}24-10 \mathrm{~A} \\
\mathrm{Gm}-3\end{array}$ & $\begin{array}{c}24-10 \mathrm{~B} \\
\mathrm{Gm}-6\end{array}$ & $\begin{array}{c}24-10 \mathrm{C} \\
\mathrm{Gm}-6\end{array}$ & $\begin{array}{c}24-10 \mathrm{C} \\
\text { Rim-3 }\end{array}$ & $\begin{array}{l}24-10 C \\
\text { Core-4 }\end{array}$ \\
\hline $\mathrm{SiO}_{2}$ & 56.03 & 57.37 & 56.22 & 55.98 & 55.80 \\
\hline $\mathrm{Al}_{2} \overline{\mathrm{O}}_{3}$ & 26.95 & 25.77 & 25.86 & 26.95 & 27.40 \\
\hline $\mathrm{FeO}$ & 0.82 & 0.84 & 0.98 & 0.49 & 0.33 \\
\hline $\mathrm{CaO}$ & 9.36 & 8.91 & 9.34 & 9.85 & 10.33 \\
\hline $\mathrm{Na}_{2} \mathrm{O}$ & 6.18 & 6.22 & 6.11 & 5.96 & 5.72 \\
\hline $\mathrm{K}_{2} \mathrm{O}$ & 0.68 & 0.87 & 0.80 & 0.55 & 0.45 \\
\hline TOTAL & 100.01 & 99.98 & 99.32 & 99.78 & 99.80 \\
\hline \multicolumn{6}{|c|}{ Based on 8 Oxygens } \\
\hline $\mathrm{Si}$ & 2.534 & 2.591 & 2.564 & 2.534 & 2.515 \\
\hline $\mathrm{Al}$ & 1.437 & 1.372 & 1.390 & 1.438 & 1.462 \\
\hline $\mathrm{Fe}$ & 0.031 & 0.032 & 0.037 & 0.019 & 0.013 \\
\hline $\mathrm{Ca}$ & 0.454 & 0.431 & 0.456 & 0.478 & 0.501 \\
\hline $\mathrm{Na}$ & 0.542 & 0.545 & 0.541 & 0.523 & 0.501 \\
\hline K & 0.039 & 0.050 & 0.047 & 0.032 & 0.026 \\
\hline TOTAL & 5.038 & 5.021 & 5.035 & 5.024 & 5.018 \\
\hline An $\%$ & $41-47$ & $40-47$ & $42-47$ & $47-48$ & $49-51$ \\
\hline
\end{tabular}

Note: $\operatorname{Rim}=$ rim of a xenocryst. Core $=$ core of a xenocryst. $\mathrm{Gm}=$ groundmass. $\mathrm{An} \%=$ range of $100 \times \mathrm{An} /$ $(\mathrm{An}+\mathrm{Ab}+\mathrm{Or})$. Analyst: M. Garcia.

TABLE 3

Composition of Interstitial Material of Feldspar Composition, Jingū Seamount (wt. \%)

\begin{tabular}{|c|c|c|c|c|c|}
\hline \multicolumn{3}{|c|}{$24-10 \mathrm{~A}$} & \multicolumn{3}{|c|}{$24-10 B$} \\
\hline $\mathrm{SiO}_{2}$ & 62.28 & 56.09 & 58.05 & 65.49 & 59.82 \\
\hline $\mathrm{Al}_{2} \mathrm{O}_{3}$ & 20.55 & 24.64 & 23.64 & 19.65 & 23.88 \\
\hline $\mathrm{FeO}$ & 0.97 & 0.73 & 1.00 & 0.77 & 0.82 \\
\hline $\mathrm{CaO}$ & 4.13 & 9.30 & 8.00 & 1.92 & 6.90 \\
\hline $\mathrm{Na}_{2} \mathrm{O}$ & 9.96 & 6.33 & 6.85 & 6.24 & 7.36 \\
\hline $\mathrm{K}_{2} \mathrm{O}$ & 4.92 & 3.34 & 1.71 & 5.39 & 1.28 \\
\hline TOTAL & 99.83 & 100.43 & 99.25 & 99.46 & 100.07 \\
\hline \multicolumn{6}{|c|}{ Based on 8 Oxygens } \\
\hline $\mathrm{Si}$ & 2.830 & 2.570 & 2.653 & 2.945 & 2.690 \\
\hline $\mathrm{Al}$ & 1.101 & 1.331 & 1.274 & 1.041 & 1.266 \\
\hline $\mathrm{Fe}$ & 0.037 & 0.028 & 0.030 & 0.029 & 0.031 \\
\hline $\mathrm{Ca}$ & 0.201 & 0.457 & 0.392 & 0.093 & 0.333 \\
\hline $\mathrm{Na}$ & 0.613 & 0.563 & 0.607 & 0.544 & 0.642 \\
\hline $\mathrm{K}$ & 0.285 & 0.195 & $\underline{0.100}$ & 0.309 & $\underline{0.074}$ \\
\hline TOTAL & 5.068 & 5.144 & 5.064 & 4.961 & 5.035 \\
\hline
\end{tabular}

Note: Analyst: M. Garcia.

Results of the conventional $\mathrm{K}-\mathrm{Ar}$, the total fusion ${ }^{40} \mathrm{Ar} /{ }^{39} \mathrm{Ar}$, and the ${ }^{40} \mathrm{Ar} /{ }^{39} \mathrm{Ar}$ incremental heating experiments are given in Tables 4 and 5, and in Figure 3.

Although the conventional and the ${ }^{40} \mathrm{Ar} /{ }^{39} \mathrm{Ar}$ total fusion ages on sample 24-10A are concordant (Table 4), the ${ }^{40} \mathrm{Ar} / 39 \mathrm{Ar}$ incremental heating results (Table 5, Figure 3) show that the sample constitutes a highly disturbed $\mathrm{K}-\mathrm{Ar}$ system. There is no convincing age spectrum plateau, and both the high index of fit [SUMS $/(\mathrm{N}-2)=2.7$ ] and the low ${ }^{40} \mathrm{Ar} /{ }^{36} \mathrm{Ar}$ intercept $(279 \pm 9)$ for the isochron are diagnostic of an unreliable sample (Lanphere and Dalrymple, 1978;
Dalrymple et al., this volume). We interpret the conventional and ${ }^{40} \mathrm{Ar} /{ }^{39} \mathrm{Ar}$ total fusion ages of $47 \mathrm{~m}$.y. (Table 4) as a minimum age for the time of crystallization.

The discordance between the ${ }^{40} \mathrm{Ar} /{ }^{39} \mathrm{Ar}$ total fusion ages (higher) and the conventional $\mathrm{K}-\mathrm{Ar}$ ages (lower) for samples 24-10B and 24-10C (Table 4) is typical for subaerially erupted Hawaiian alkalic rocks that have been altered in the submarine environment. Dalrymple and Clague (1976) proposed that the higher ${ }^{40} \mathrm{Ar} /{ }^{39} \mathrm{Ar}$ total fusion ages were probably caused by proportional loss of both radiogenic ${ }^{40} \mathrm{Ar}$ and $\mathrm{K}$-derived ${ }^{39} \mathrm{Ar}$ (perhaps at different times and by different mechanisms) from K-bearing montmorillonitic clays; they also showed that the ${ }^{40} \mathrm{Ar} /{ }^{39} \mathrm{Ar}$ total fusion ages may approach or even equal crystallization ages. They argued that the conventional $\mathrm{K}-\mathrm{Ar}$ ages on such samples would be low because the clays contribute potassium to the analysis but do not retain radiogenic ${ }^{40} \mathrm{Ar}$.

The ${ }^{40} \mathrm{Ar} /{ }^{39} \mathrm{Ar}$ incremental heating results from sample 24-10B resemble those found for altered samples of alkalic basalt from seamounts on the HawaiianEmperor bend (Dalrymple and Clague, 1976). This sample has a low-temperature plateau at $55.2 \pm 0.6 \mathrm{~m} . \mathrm{y}$. for 65 per cent of the gas released and a concordant isochron at $54.7 \pm 0.8 \mathrm{~m}$.y. (Figure 3). The isochron index of fit for the $500^{\circ} \mathrm{C}-700^{\circ} \mathrm{C}$ increments is good [SUMS/ $(\mathrm{N}-2)=0.3]$, and the ${ }^{40} \mathrm{Ar} /{ }^{36} \mathrm{Ar}$ intercept $(302 \pm 11)$ is indistinguishable from the atmospheric value of 295.5. The absence of a high-temperature age spectrum plateau, however, suggests that the results from this sample should be interpreted cautiously.

Sample 24-10C has a classical high-temperature plateau at $55.1 \pm 0.9 \mathrm{~m} . \mathrm{y}$. for 81 per cent of the ${ }^{39} \mathrm{Ar}$ released, and a concordant isochron at $55.4 \pm 0.9 \mathrm{~m}$.y. The isochron index of fit [SUMS/ $(\mathrm{N}-2)=0.4]$ and the ${ }^{40} \mathrm{Ar} /{ }^{36} \mathrm{Ar}$ intercept $(294 \pm 4)$ also are indicative of a reliable age. We interpret the data from this sample as representing the age of crystallization.

The best estimate for the age of Jingu Seamount is provided by the data from sample 24-10C. We prefer to use the isochron age of $55.4 \pm 0.9 \mathrm{~m} . \mathrm{y}$. because it requires no numerical assumption about the composition of the atmospheric component. This age is substantiated by the ${ }^{40} \mathrm{Ar} /{ }^{39} \mathrm{Ar}$ incremental heating results from sample 24-10B, which also give ages of about $55 \mathrm{~m}$.y. If the isochron ages from samples $24-10 \mathrm{~B}$ and $24-10 \mathrm{C}$ are averaged, the result is $55.0 \pm 0.6 \mathrm{~m} . \mathrm{y}$.

The Jingu age of $55.4 \pm 0.9 \mathrm{~m} . \mathrm{y}$. is the same as the age found for its neighbor to the south, Ōjin Seamount $(55.2 \pm 0.7 \mathrm{~m} . \mathrm{y}$.$) , and is younger than Nintoku (56.2 \pm$ 0.6 m.y.), and Suiko $(64.7 \pm 1.1$ m.y.) seamounts to the north (Dalrymple et al., this volume). Jingū is also significantly older than both Kōkō Seamount (48.1 \pm 0.8 m.y.; Clague and Dalrymple, 1973) and the Hawaiian-Emperor bend (43 m.y.: Dalrymple and Clague, 1976). The age results from Jingū Seamount thus confirm the progression in the ages of the Emperor Seamounts from south to north, as predicted by the hotspot hypothesis. 

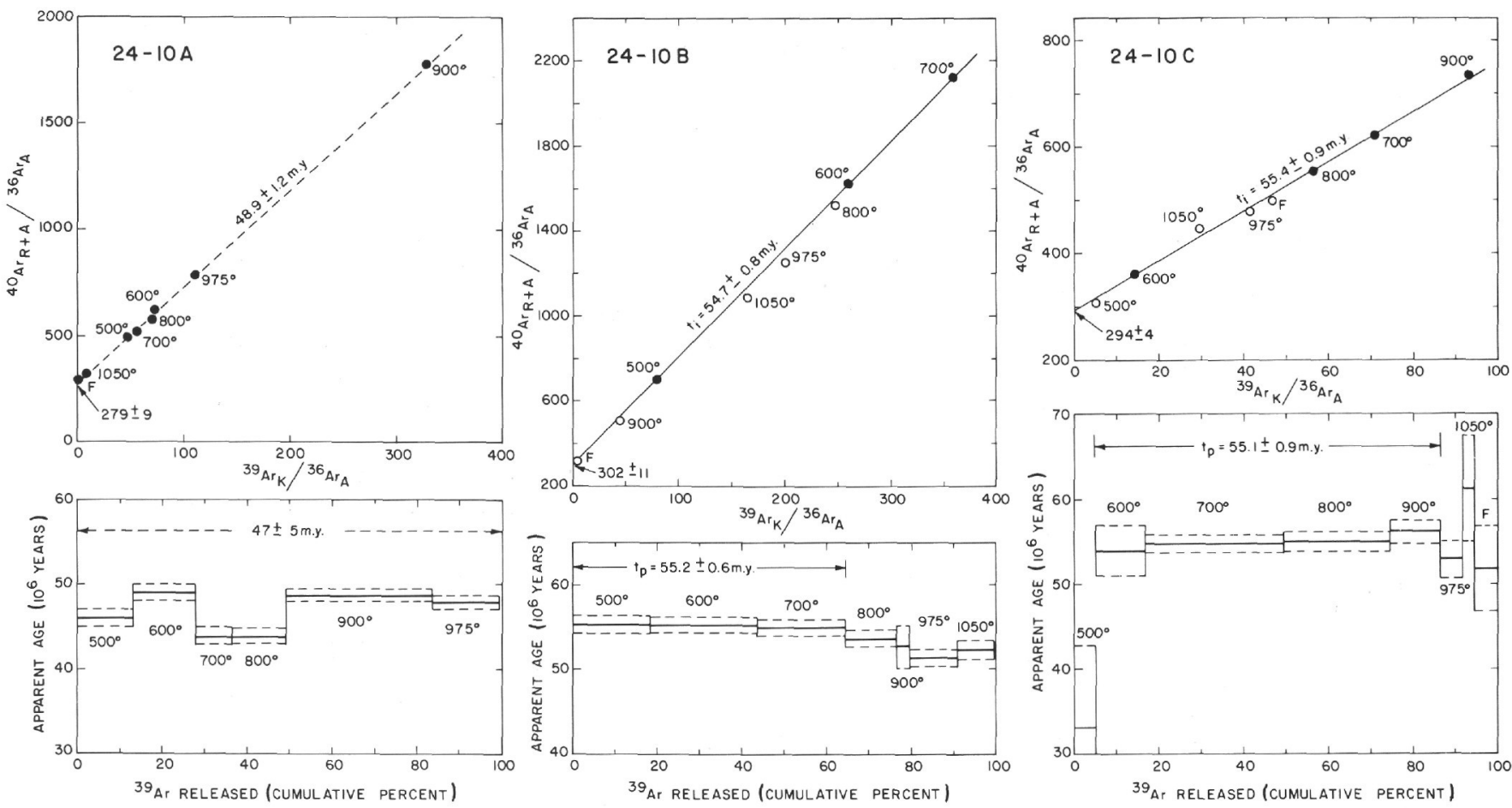

Figure 3. ${ }^{40} \mathrm{Ar} /{ }^{39} \mathrm{Ar}$ age spectra and isochron diagrams for three samples $(A, B$, and $C)$ from $R / V$ Kana Keoki station 24, dredge 10. Dashed lines on age spectra indicate standard deviation of analytical precision about the apparent age (solid lines) of each gas increment. For isochron diagrams, the isochron was calculated using only the gas increments indicated by filled circles. The weighted mean plateau age $\left(\mathrm{t}_{\mathrm{p}}\right)$ and the isochron age $\left(\mathrm{t}_{\mathrm{i}}\right)$ are for the same gas increments. Temperatures are in degrees Celsius. Subscripts $R, A$, and $K$ represent radiogenic, atmospheric, and $K$-derived Ar, respectively. The age spectrum and isochron ages for Sample 24-10A are not considered to be crystallization ages, and are shown for reference only.

TABLE 4

Conventional K-Ar and Total Fusion $40_{\mathrm{Ar}} /{ }^{39} \mathrm{Ar}$ Ages on Whole-Rock Mugearites from Jingū Seamount, Emperor Seamount Chain

\begin{tabular}{|c|c|c|c|c|c|c|c|c|}
\hline \multirow[b]{2}{*}{ Sample } & \multirow{2}{*}{\multicolumn{2}{|c|}{$\begin{array}{l}\mathrm{K}_{2} \mathrm{O}^{\mathrm{a}} \\
\text { (Wt. } \% \text { ) }\end{array}$}} & \multicolumn{5}{|c|}{ Argon $b$} & \multirow[b]{2}{*}{$\begin{array}{c}\text { Calculated Agec } \\
\text { (106 years) }\end{array}$} \\
\hline & & & $\begin{array}{l}\text { Weight } \\
\text { (g) }\end{array}$ & \multicolumn{2}{|l|}{$\begin{array}{l}{ }^{40} \mathrm{ArR} \\
(\mathrm{Mol} / \mathrm{g})\end{array}$} & & $\begin{array}{c}{ }^{40} \mathrm{ArR} \\
(\%)\end{array}$ & \\
\hline $24-10 \mathrm{~A}$ & \multicolumn{2}{|c|}{$2.922 \pm 0.005$} & $\begin{array}{l}3.843 \\
4.173\end{array}$ & \multicolumn{2}{|c|}{$\begin{array}{l}2.014 \times 10^{-10} \\
2.001\end{array}$} & & 78.9 & $47.1 \pm 0.7$ \\
\hline $24-10 \mathrm{~B}$ & \multicolumn{2}{|c|}{$1.504 \pm 0.005$} & $\begin{array}{l}3.175 \\
2.812\end{array}$ & $\begin{array}{l}1.076 \\
1.084\end{array}$ & & & $\begin{array}{l}60.3 \\
45.4\end{array}$ & $49.2 \pm 0.7$ \\
\hline \multirow[t]{3}{*}{$24-10 \mathrm{C}$} & 1.70 & 0.003 & $\begin{array}{l}4.347 \\
3.287\end{array}$ & $\begin{array}{l}0.955 \\
0.955\end{array}$ & & & $\begin{array}{l}68.5 \\
34.7\end{array}$ & $38.6 \pm 0.5$ \\
\hline & \multicolumn{7}{|c|}{$40 \mathrm{Ar} /{ }^{39} \mathrm{Ar}$ Analy ses $\mathrm{b}$} & \\
\hline & $\mathrm{J}$ & ${ }^{40} \mathrm{Ar} /{ }^{39} \mathrm{Ar}$ & ${ }^{37} \mathrm{Ar} /{ }^{39} \mathrm{Ar} d$ & $36_{\mathrm{Ar}} /{ }^{39} \mathrm{Ar}$ & $\begin{array}{c}36{ }_{\mathrm{Ar}} \mathrm{Ca} \\
(\%)\end{array}$ & $\begin{array}{c}{ }^{40} \mathrm{Ar}_{\mathrm{K}} \\
(\%)\end{array}$ & $\begin{array}{c}{ }^{40} \mathrm{Ar}_{\mathrm{R}} \\
(\%)\end{array}$ & \\
\hline $24-10 \mathrm{~A}$ & 0.00606 & 9.389 & 1.157 & 0.01726 & 1.8 & $<0.1$ & 46.6 & $47.2 \pm 0.9$ \\
\hline $24-10 B$ & 0.00606 & 8.267 & 2.175 & 0.01182 & 5.0 & $<0.1$ & 59.8 & $53.3 \pm 0.9$ \\
\hline $24-10 \mathrm{C}$ & 0.00563 & 10.54 & 2.507 & 0.01808 & 3.8 & $<0.1$ & 51.2 & $54.1 \pm 1.0$ \\
\hline
\end{tabular}

aCalculated mean and standard deviation of four measurements.

${ }^{\mathrm{b}} 40 \mathrm{Ar}_{\mathrm{R}}=$ radiogenic ${ }^{40} \mathrm{Ar},{ }^{36} \mathrm{Ar}_{\mathrm{Ca}}=$ calcium-derived ${ }^{36} \mathrm{Ar},{ }^{40} \mathrm{Ar} \mathrm{K}=$ potassium-derived ${ }^{40} \mathrm{Ar}$.

$c_{\lambda_{\epsilon}}+\lambda_{\epsilon}{ }^{\prime}=0.581 \times 10^{-10} \mathrm{yr}^{-1}, \lambda_{\beta}=4.962 \times 10^{-10} \mathrm{yr}^{-1} .40 \mathrm{~K} / \mathrm{K}=1.167 \times 10^{-4} \mathrm{~mol} / \mathrm{mol}$. Errors are estimated standard deviations of analytical precision (Cox and Dalrymple, 1967; Dalrymple and Lanphere, 1971).

$\mathrm{d}_{\text {Corrected for }}{ }^{37} \mathrm{Ar}$ decay, $\mathrm{t}_{1 / 2}=35.1$ days. 
TABLE 5

Analy tical Data for ${ }^{40} \mathrm{Ar} /{ }^{39} \mathrm{Ar}$ Incremental Heating Experiments on Volcanic Rocks (Mugearites) Dredged from Jingū Seamount, Emperor Seamounts

\begin{tabular}{|c|c|c|c|c|c|c|c|c|c|}
\hline Sample & $\begin{array}{c}\text { Temp } \\
\left({ }^{\circ} \mathrm{C}\right)\end{array}$ & ${ }^{40} \mathrm{Ar} /{ }^{39} \mathrm{Ar}$ & ${ }^{37} \mathrm{Ar} /{ }^{39} \mathrm{Ar}^{\mathrm{a}}$ & ${ }^{36} \mathrm{Ar} /{ }^{39} \mathrm{Ar}$ & $\begin{array}{c}{ }^{39} \mathrm{Ar} \\
(\% \text { of total) }\end{array}$ & $\begin{array}{c}40 \mathrm{ArR}_{\mathrm{R}} \\
(\%)\end{array}$ & $\begin{array}{c}{ }^{36} \mathrm{Ar} \mathrm{Ca} \\
(\%)\end{array}$ & \multicolumn{2}{|c|}{$\begin{array}{c}\text { Apparent Ageb } \\
\left(10^{6} \text { years }\right)\end{array}$} \\
\hline \multirow{11}{*}{$\begin{array}{l}24-10 \mathrm{~A} \\
(\mathrm{~J}=0.006059)\end{array}$} & 500 & 10.57 & 0.743 & 0.0216 & 13.3 & 40.2 & 0.9 & $46.0 \pm$ & 1.1 \\
\hline & 600 & 8.62 & 0.911 & 0.0140 & 14.7 & 52.7 & 1.8 & $49.0 \pm$ & 1.0 \\
\hline & 700 & 9.33 & 1.840 & 0.0184 & 8.6 & 43.4 & 2.7 & $43.8 \pm$ & 1.1 \\
\hline & 800 & 8.27 & 0.919 & 0.0145 & 12.7 & 49.0 & 1.7 & $43.8 \pm$ & 0.9 \\
\hline & 900 & 5.42 & 0.800 & 0.00325 & 34.2 & 83.3 & 6.7 & $48.7 \pm$ & 0.7 \\
\hline & 975 & 7.10 & 1.896 & 0.00951 & 16.0 & 62.5 & 5.4 & $47.9 \pm$ & 0.8 \\
\hline & 1050 & 41.94 & 12.40 & 0.1326 & 0.5 & 8.9 & 2.5 & $40.8 \pm$ & 13.6 \\
\hline & Fuse & 429.3 & 1.778 & 1.435 & 0.04 & 1.2 & $<0.1$ & 56. \pm 2 & 235. \\
\hline & & & & & \multicolumn{3}{|l|}{100.0} & & \\
\hline & & & & & \multirow{2}{*}{\multicolumn{3}{|c|}{$\begin{array}{l}\text { Recalculated total fusion age }= \\
\text { Recalculated total }{ }^{40} \mathrm{Ar}_{\mathrm{R}} /{ }^{39} \mathrm{Ar}_{\mathrm{K}}= \\
\text { Total }{ }^{40} \mathrm{Ar}_{\mathrm{R}}=2.07 \times 10^{-10} \mathrm{~mol} / \mathrm{g}\end{array}$}} & $47.2 \pm$ & 1.4 \\
\hline & & & & & & & & 4.374 & \\
\hline \multirow{11}{*}{$\begin{array}{l}24-10 \mathrm{~B} \\
(\mathrm{~J}=0.006059)\end{array}$} & 500 & 8.84 & 0.980 & 0.0128 & 18.5 & 58.1 & 2.1 & $55.3 \pm$ & 1.2 \\
\hline & 600 & 6.27 & 1.053 & 0.00413 & 25.3 & 81.8 & 6.9 & $55.2 \pm$ & 0.9 \\
\hline & 700 & 5.94 & 1.491 & 0.00319 & 20.7 & 86.0 & 12.7 & $55.1 \pm$ & 0.9 \\
\hline & 800 & 6.18 & 1.627 & 0.00449 & 12.0 & 80.6 & 9.9 & $53.7 \pm$ & 1.0 \\
\hline & 900 & 11.57 & 2.882 & 0.0234 & 3.1 & 42.3 & 3.4 & $52.8 \pm$ & 2.5 \\
\hline & 975 & 6.21 & 5.39 & 0.00639 & 11.5 & 76.5 & 22.9 & $51.3 \pm$ & 0.9 \\
\hline & 1050 & 6.63 & 6.37 & 0.00778 & 8.5 & 73.0 & 22.3 & $52.3 \pm$ & 1.1 \\
\hline & Fuse & 73.8 & 6.16 & 0.229 & 0.3 & 8.9 & 0.7 & 70. \pm & 24. \\
\hline & & & & & \multicolumn{3}{|l|}{99.9} & & \\
\hline & & & & & \multirow{2}{*}{\multicolumn{3}{|c|}{$\begin{array}{l}\text { Recalculated total fusion age }= \\
\text { Recalculated total }{ }^{40} \operatorname{Ar}_{\mathrm{R}} /{ }^{39} \mathrm{Ar}_{\mathrm{K}}= \\
\text { Total }{ }^{40}{ }^{\mathrm{Ar}} \mathrm{R}=1.123 \times 10^{-10} \mathrm{~mol} / \mathrm{g}\end{array}$}} & $54.3 \pm$ & 1.6 \\
\hline & & & & & & & & 5.043 & \\
\hline \multirow{11}{*}{$\begin{array}{l}24-10 \mathrm{C} \\
(\mathrm{J}=0.006743)\end{array}$} & 500 & 59.4 & 0.841 & 0.192 & 5.3 & 4.6 & 0.1 & $33.2 \pm$ & 9.6 \\
\hline & 600 & 24.76 & 1.204 & 0.0688 & 11.7 & 18.2 & 0.5 & $54.0 \pm$ & 3.0 \\
\hline & 700 & 8.72 & 1.446 & 0.0144 & 32.7 & 52.4 & 2.7 & $54.8 \pm$ & 1.1 \\
\hline & 800 & 9.84 & 1.468 & 0.0181 & 24.9 & 46.6 & 2.2 & $55.0 \pm$ & 1.2 \\
\hline & 900 & 7.85 & 1.753 & 0.0112 & 11.8 & 59.7 & 4.3 & $56.2 \pm$ & 1.5 \\
\hline & 975 & 11.52 & 1.997 & 0.0246 & 5.3 & 38.2 & 2.2 & $52.9 \pm$ & 2.2 \\
\hline & 1050 & 15.05 & 2.541 & 0.0343 & 2.8 & 33.9 & 2.0 & $61.2 \pm$ & 6.2 \\
\hline & Fuse & 10.61 & 5.01 & 0.0227 & 5.6 & 40.6 & 6.0 & $51.8 \pm$ & 5.0 \\
\hline & & & & & \multicolumn{3}{|l|}{100.1} & & \\
\hline & & & & & \multirow{2}{*}{\multicolumn{3}{|c|}{$\begin{array}{l}\text { Recalculated total fusion age }= \\
\text { Recalculated total } 40{ }_{A_{R}} / 39 A_{\mathrm{Ar}}= \\
\text { Total } 40_{\mathrm{Ar}}=0.867 \times 10^{-10} \mathrm{~mol} / \mathrm{g}\end{array}$}} & $53.7 \pm$ & 1.6 \\
\hline & & & & & & & & 4.481 & \\
\hline
\end{tabular}

a Corrected for ${ }^{37} \mathrm{Ar}$ decay, half-life $=35.1$ days.

$\mathrm{b}_{\lambda_{\epsilon}}+\lambda_{\epsilon}^{\prime}=0.581 \times 10^{-10} \mathrm{yr}-1, \lambda_{\beta}=4.962 \times 10^{-10} \mathrm{yr}^{-1}$. Errors are estimates of the standard deviation of precision.

\section{ACKNOWLEDGMENTS}

We thank S. E. Sims, B. M. Myers, and J. C. Von Essen for assistance with the argon measurements and data reduction; P. Klock for the potassium measurements; J. Saburomaru for sample preparation; and P. Helfer and the staff of the GSTR for irradiating the samples for the ${ }^{40} \mathrm{Ar} /{ }^{39} \mathrm{Ar}$ experiments. We also appreciate the time and advice of our colleagues M. H. Beeson, M. A. Lanphere, J. J. Naughton, and J. M. Sinton, who reviewed the manuscript. This research was funded in part by the Office of Naval Research.

\section{REFERENCES}

Albee, A. L. and Ray, L., 1970. Correction factors for electronprobe microanalysis of silicates, carbonates, phosphates and sulfates, Analyt. Chem., v. 42, pp. 1408-1414.

Bargar, K. E. and Jackson, E. D., 1974. Calculated volumes of individual shield volcanoes along the Hawaiian-Emperor chain, J. Res. U.S. Geol. Surv., v. 2, pp. 545-550.
Bence, A. E. and Albee, A. L., 1968. Empirical correction factors for the electron microprobe analysis of silicates and oxides, J. Geol., v. 76, pp. 382-403.

Cann, J. R., 1969. Spilites from the Carlsberg Ridge, Indian Ocean, J. Petrol., v. 10, pp. 1-19.

Chase, T. E., Menard, H. W., and Mammerickx, J., 1970. Bathymetry of the North Pacific, Chart 7, Inst. Marine Resources, Scripps Inst. Oceanography.

Christofferson, E., 1968. The relationship of sea-floor spreading in the Pacific to the origin of the Emperor Seamounts and the Hawaiian Island Chain [abs], $A G U$ Trans., v. 19, p. 214.

Clague, D. A. and Dalrymple, G. B., 1973. Age of Kōkō Seamount, Emperor Seamount chain, Earth Planet. Sci. Letters, v. 17, pp. 411-415.

Coombs, D. S. and Wilkinson, J. F. G., 1969. Lineages and fractionation trends in undersaturated volcanic rocks from the East Otago Volcanic Province (New Zealand) and related rocks, J. Petrol., v. 10, pp. 440-501. 
Cox, A. and Dalrymple, G. B., 1967. Statistical analysis of geomagnetic reversal data and the precision of potassium-argon dating, J. Geophys. Res., v. 72, pp. 2603-2614.

Dalrymple, G. B. and Clague, D. A., 1976. Age of the Hawaiian-Emperor bend, Earth Planet. Sci. Letters, v. 31, pp. 313-329.

Dalrymple, G. B. and Lanphere, M. A., 1969. PotassiumArgon Dating. San Francisco (W. H. Freeman \& Co.). , 1971. ${ }^{40} \mathrm{Ar} /{ }^{39} \mathrm{Ar}$ technique of $\mathrm{K}-\mathrm{Ar}$ dating: A comparison with the conventional technique, Earth Planet. Sci. Letters, v. 12, pp. 300-308. 1974. ${ }^{40} \mathrm{Ar} / 39 \mathrm{Ar}$ age spectra of some undisturbed terrestrial samples, Geochim. Cosmochim. Acta, v. 38, pp. 715-738.

Flanagan, F. J., 1973. 1972 values for international geochemical references samples, Geochim. Cosmochim. Acta., v. 37, pp. 1189-1200.

Greene, H. G., Dalrymple, G. B., and Clague, D. A., 1978. Evidence for northward movement of the Emperor Seamounts, Geology, v. 6, pp. 70-74.

Hart, S. R., Erlak, A. J., and Kable, E. J. D., 1974. Sea floor basalt alteration: some chemical and $\mathrm{Sr}$ isotope effects, Contrib. Mineral. Petrol., v. 44, pp. 219-240.

Ingamells, C. O., 1970. Lithium metaborate flux in silicate analysis, Anal. Chim. Acta, v. 52, pp. 323-334.

Jackson, E. D., 1976. Linear volcanic chains on the Pacific plate. In Sutton, G. H., Manghanani, M. H., and Moberly, R. (Ed.), The Geophysics of the Pacific Ocean Basin and Its Margin: Am. Geophys. Union Mon. 19, pp. 319-335.

Jarrard, R. D. and Clague, D. A., 1977. Implications of Pacific island and seamount ages for the origin of volcanic chains, Rev. Geophys. and Space Physics, v. 15, pp. 57-76.

Keil, K., Fodor, R. V., and Bunch, T. E., 1972. Contributions to the mineral chemistry of Hawaiian rocks: II. Feldspars in rocks from Haleakala and West Maui volcanoes, Maui, Hawaii, Contrib. Mineral. Petrol., v. 37, pp. 253-276.

Lanphere, M. A. and Dalrymple, G. B., 1971. A test of the ${ }^{40} \mathrm{Ar} /{ }^{39} \mathrm{Ar}$ age spectrum technique on some terrestrial materials, Earth Planet. Sci. Letters, v. 12, pp. 350-372. , 1978. The use of ${ }^{40} \mathrm{Ar} /{ }^{39} \mathrm{Ar}$ data in evaluation of disturbed K-Ar systems. In Zartman, R. E. (Ed.), Short papers of the Fourth International Conference, Geochronology, Cosmochronology, Isotope Geology, U.S. Geol. Surv. Open-File Report 78-701, pp. 241-243 (abstract).

Macdonald, G. A., 1960. Dissimilarity of continental and oceanic rock types, J. Petrol., v. 1, pp. 172-177.

1968. Composition and origin of Hawaiian lavas, Geol. Soc. Am. Mem. 116, pp. 477-522.

Macdonald, G. A. and Katsura, T., 1964. Chemical composition of Hawaiian lavas, J. Petrol., v. 5, pp. 82-133.

Morgan, W. J., 1972. Plate motions and deep mantle convection In Shagam, R., et al. (Eds.), Studies in Earth and Space Sciences (Hess Vol.): Geol. Soc. Am. Mem. 132, pp. $7-22$.

Muir, I. D. and Tilley, C. E., 1961. Mugearites and their place in alkalic igneous rock series, J. Geol., v. 69, pp. 186-203.

Price, R. C. and Chappell, B. W., 1975. Fractional crystallization and the petrology of Dunedin Volcano, Contrib. Mineral. Petrol., v. 53, pp. 157-182.

Stacey, J. S., Sherrill, N. D., Dalrymple, G. B., Lanphere, M. A., and Carpenter, N. V., 1978. A computercontrolled, five-collector mass spectrometer for precision measurement of argon isotope ratios. In Zartman, R. E. (ed.), Short papers of the Fourth International Conference, Geochronology, Cosmochronology, Isotope Geology, U.S. Geol. Surv. Open-File Report 78-701, pp. 411-413 (abstract).

Steiger, R. H. and Jäger, E., 1977. Subcommission on Geochronology: Convention on the use of decay constants in geo- and cosmochronology, Earth Planet. Sci. Letters, v. 36, pp. 359-362.

Streckeisen, A., 1976. Classification of the common igneous rocks by means of their chemical composition, a provisional attempt, N. Jahrbuch f. Mineral. Jg. 1976, H. 1, pp. $1-15$.

Wilson, J. T., 1963. A possible origin of the Hawaiian Islands, J. Physics, v. 41, pp. 863-870.

York, D., 1969. Least squares fitting of a straight line with correlated errors, Earth Planet. Sci. Letters, v. 5, pp. 320-324. 
PLATE 1

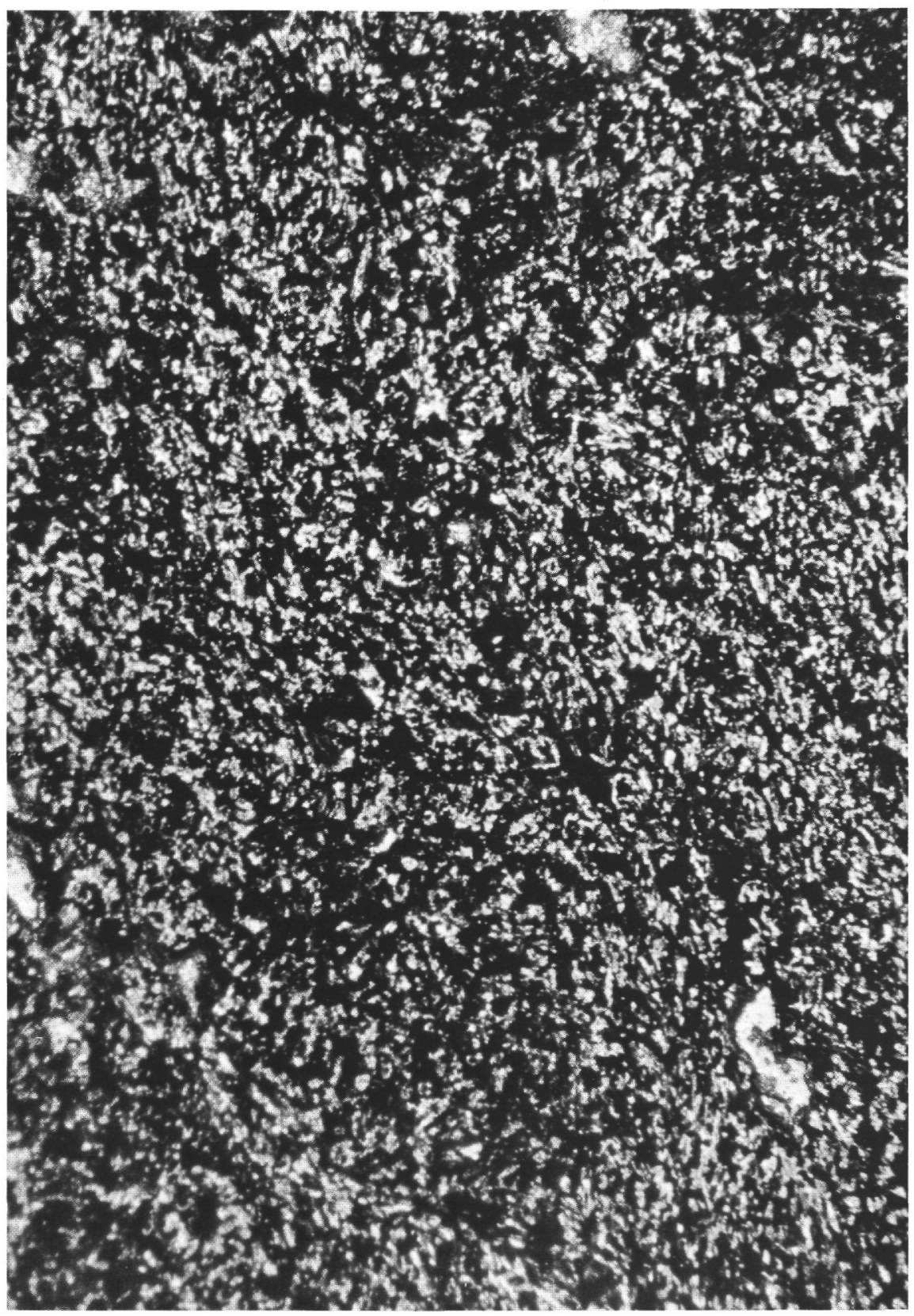

Photomicrograph of Sample 24-10A. 
PLATE 2

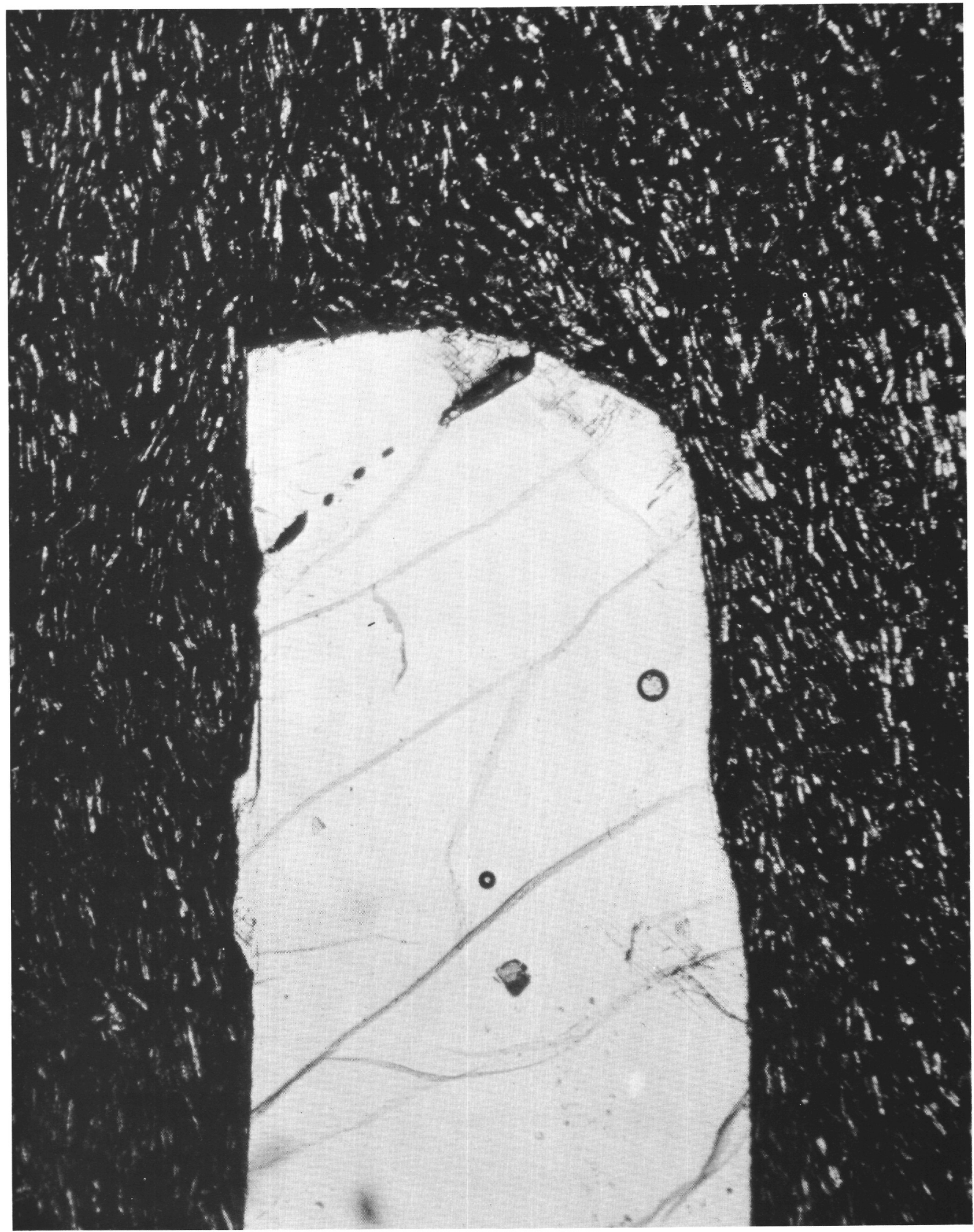

Photomicrograph of Sample 24-10B. 